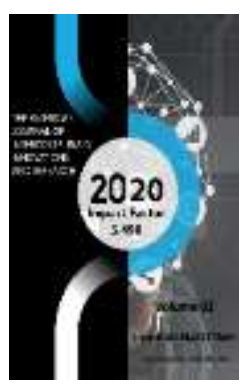

\title{
Distribution Of Blood Sucking Mosquitoes Of The Family Culicidae Found In The Reservoirs Of Surkhandarya
}

\author{
Gavxar Dobilovna Mardonova \\ Teacher Of The Department Of Zoology, Termez State University, Termez, Uzbekistan
}

Journal Website: http://usajournalshub.c om/index,php/tajiir

Copyright: Original content from this work may be used under the terms of the creative commons attributes 4.0 licence.

\section{ABSTRACT}

The article presents materials on the distribution of blood-sucking mosquitoes of the family Culicidae found in reservoirs of Surkhandarya region, daily and seasonal development of malarial pathogens, main water sources, materials and methods of catching mosquitoes in places of their mass breeding.

\section{KEYWORDS}

Blood-sucking mosquitoes, malaria, water sources, glacial and seasonal ground water, reservoirs, floodplain, spring and summer floods, springs, swamps, puddles

\section{INTRODUCTION}

The main water sources of Surkhandarya region are Amu Darya and Surkhandarya with tributaries Dashnabad, Khodjaipak, Sangardak, Tupalang, Karatag, Sherabad. Karatag and Tupalang are fed by snow, glacial and seasonally-ground water, the rest-snow and seasonally-ground in rivers of mixed type of nutrition spring and summer floods are noted from may to mid-July, then the rivers begin to quickly and strongly shallow; in addition, 
flowing in pebbles, they lose a lot of water, Floodplains of mountain rivers with many springs in their spring inclusions sometimes form swamps overgrown with tamarisk and reeds. Usually, these rivers are covered with water during the flood period. In the second half of summer, water from the river is completely taken for irrigation of crops in the riverbeds, water usually remains only in the depressions. Small reservoirs overgrown with green filamentous algae are places where a huge number of mosquitoes hatch.

\section{MATERIALS AND METHODS}

The study of the ecology and phenology of blood-sucking mosquitoes was carried out year-round by observing natural biotopes and the floodplain of the Surkhandarya river. To determine the species composition and distribution of insects, route surveys covered various types of reservoirs. Larvae of their reservoirs were caught using a $20 \mathrm{~cm}$ diameter haze net.to collect mosquitoes in rooms and caves, test tubes and special gauze traps were used (a 10x10x10 cm cage connected to a glass tube). They were collected from grassy vegetation by covering the grass with a canopy. Larvae of III-IV instars and winged mosquitoes were determined by species.

According to the results of research in the Nezhnesurkhan district on the cone of the Sherabad river outflow, the soils are sandy-clay with different depths of salty ground water. Salinization and waterlogging of soils here is caused by insufficiently regulated discharge of water after irrigation. Ground water fills the lowlands, where Aedes mosquitoes live in large numbers. In Uchkyzyl reservoir in which water enters from R.Surkhandarya during the flood period, mosquitoes are almost impossible to get rid of.

There are not enough hydraulic structures in the irrigation network of Surkhandarya region, many channels are in a neglected state. Poor irrigation regime contributes to the formation of small temporary reservoirs (as a result of filtration breakout and seepage from the channel), which are places of breeding of blood-sucking mosquitoes. This situation is observed, in particular, in collective and state farms located in the floodplain parts of the Srednesurkhansky and Nezhnesurkhansky districts.

Our collections included mosquito species found in the surrounding areas, as well as in other regions of the country with similar elevated conditions: A. lindesayi Giles, A. marteri senevet et prunell; A. plumbeus Stephens, AE. cinereus meig., C. univittatus theob.; AE. geniculatus oliv; C. tritaeniorhynchus Giles; AE. flavescens Mull., AE. leucomelas meig. / AE. cataphyila dyar; C. (theobaldia) alaskaensis var. indica EDV.

In the territory we surveyed in the Surkhandarya region, the main breeding sites of blood-sucking mosquitoes in qualitative and quantitative terms were confined to the coastal part of swamps, swamps, and various puddles.

The villages of Sayrob, Derbent and Baisun of the Baisun district, Oiborik and Sina of the Denau district are among the iced points in the mountainous part of the Surkhandarya region. In all villages, the riverbeds of the Sherabad river were unsuitable for settlement by mosquito larvae until the beginning of July due to the high water content, sharp fluctuations in the water level and its low temperature (6-10 oC). The height of the localities is $1100-2000$ meters or more above sea level.

Since mid-summer, a decrease in the water level in rivers led to their partial or complete drying up, which contributed to the formation of numerous, mostly small, reservoirs in the riverbeds, fed by water infiltration from the ongoing underground flow. Such reservoirs quickly became places of mass hatching of a . superpictus larvae and moderate amounts of $C$. hortensis and $A$. slaviger. In addition to 
floodplain rivers, swamps with poor surface vegetation were occasionally found in the deep gorges of mountainous regions. In such reservoirs, larvae of $C$. longiareolata and $C$. hortensis were also found in large numbers (over 1000 larvae per $1 \mathrm{~m} 2$ ). In spring there were very zabolochennaya $A$. claviger. In the village of Sina, Denau district, larvae of Ae. pulchritarsis asiaticus were found in puddles under the cliffs of saya and in the root zone of a felled tree. The main mass bloodsucker on humans is $A$. superpictus.

In the foothill-Adyr part of Surkhandarya region, we covered the route survey of villages. Baskurt and its surroundings, the city of Sherabad and Denau, Sariasiya, Uzun and sho'rchi. In the Council of Europe. Passort in pools floodplain saya found many larvae of $A$. superpictus, and in small spring - A. claviger. In some places, these reservoirs contained a small number of Ae. vexans, $C$. hortensis, $C$. longiareolata, C. pipiens, A. hurcanus, A. m. v. sacharovi, C. modestus, and occasionally A. pulcherrimus.

We examined the reservoirs of the plain part of the Sherabad, Angora, Jarkurgan, and Termez districts. Coastal parts of bogs of ground and discharge origin, temporary pools with brackish water were populated in large numbers by larvae of Ae. caspius caspius, from which rare specimens of Ae. detritus and C. Pusillus were found. In holes near irrigation channels with poor vegetation and the smell of hydrogen sulfide, larvae of $C$. Theileri and Pusillus were found with a high density in swamps with a large debit of ground water overgrown with reeds, A. hurcanus, A. slaviger, A. algerinsis, C. modestus, C. martinii, C. apicalis, C. pusillus, C. longiareolata, $C$. annulata var. sulocherea, Ur. unguinulata, M. richiardii. In the floodplains of Surkhandarya, there are many bays with stagnant water, water holes seeping spring and many puddles with filtration water of the river. Bays overgrown with reeds and other vegetation gradually turn into a permanent floodplain swamp. During the spring and summer floods, they communicate with the main riverbed and when the water subsides, they are populated by larvae of A. hurcanus, A. pulcherrimus, A. superpictus, C. annulata var. subochrea, C. modestus, Ur. unguinulata, and A. slaviger. The dominant species since July is the larvae of $A$. pulcherrimus, A. superpictus. (table 1). In mochegonnah popodaet exclusively A. claviger, but their number was extremely small. Only A. superpictus larvae have been recorded in large numbers in puddles on sandy banks.

Table 1

Occurrence of mosquito species in swamps of the Surkhandarya river floodplain, in \%

\begin{tabular}{|c|c|c|c|c|c|}
\hline № & View & June & July & August & September \\
\hline 1 & A. hyrcanus & 13,0 & 6,8 & 19,8 & 4,4 \\
\hline 2 & A. superpictus & - & 2,6 & 9,9 & 21,2 \\
\hline 3 & A. pulcherrimus & 2,3 & 3,5 & 39,0 & 41,8 \\
\hline 4 & A. claviger & - & 0,2 & - & - \\
\hline 5 & C. pipiens & 20,6 & 13,8 & - & - \\
\hline
\end{tabular}


The American Journal of Interdisciplinary Innovations and Research (ISSN-2642-7478)

Published: October 31, 2020 | Pages: 90-96

Doi: https://doi.org/10.37547/tajiir/Volumeo2Issue10-16

\begin{tabular}{|c|c|c|c|c|c|}
\hline 6 & C. theileri & 1,5 & - & 13,7 & 10,6 \\
\hline 7 & C. mimeticus & - & - & - & 1,8 \\
\hline 8 & C. pusillus & - & 23,5 & 4,8 & 3,5 \\
\hline 9 & C. modestus & - & 0,4 & - & - \\
\hline 10 & C. martinii & - & - & - & 3,5 \\
\hline 11 & C. longiareolata & - & 0,4 & 0,2 & - \\
\hline 12 & C. an. var. subochrea & - & - & 12,6 & 7,1 \\
\hline 13 & Ae. Caspius caspius & 58,1 & 13,8 & - & - \\
\hline 14 & Ur. unguiculata & 1,5 & - & - & 2,6 \\
\hline
\end{tabular}

The larva of A. pulcherrimus are particularly prevalent in riparian zabolochennaya rivers, the Amu Darya and Surkhandarya, as well as in swamps and seepage of waste origin in the conditions of irrigated agriculture in nizhneserginskom area. A. claviger and C. martinii were observed episodecast, often vesnoy and fall in swamps and kollektornodrainage network.

Having studied the distribution of mosquito larvae in reservoirs of various types, it can be noted that floodplains of rivers that are places of mass breeding of $A$. pulcherrimus, $A$. superpictus and $A$. hurcanus larvae are of great epidemiological importance. In the pre-Adyr part, A. superpictus, A. slaviger, and A. hurcanus are flattened in springs. $C$. hortensis and $\mathrm{C}$. longiareolata are typical for the springy infiltration swamps of the mountain part.

The results of research to find out the locations of the winged stage of mosquitoes in the mountain zone show that they mainly day in nature. In the Baysun district of Surkhandarya region, the main places where mosquitoes landed were cracks in rocks and steep walls of river valleys, rodent burrows, bird nests, earthen and stony caves, and vegetation in swampy floodplains. In residential buildings from may to September inclusive, we were able to find only a single instance of $A$. superpictus.

A. M. V. Sacharovi, A. algeriensis, A. superpictus, $A$. hurcanus, $A$. pulcherrimus, and S. appisha VAR were found in the floodplain reed-reed marshes of the Amu Darya river adjacent to the city of Termez. Subochrea, $\mathrm{C}$. longiareolata, m. richiardii, C. modestus, C. pipiens, C. mimeticus, Ae. caspius caspius, Ae. vexans.

In September, larvae of Ur. unguiculata and C. martinii were found in the collector-drainage network of the plain zone.

There are 4 species of Anopheles in Surkhandarya region, and 4 of them belong to the Termez region: $A$. hurcanus, $A$. superpictus, $A$. pulcherrimus and $A$. slaviger.

A. pulcherrimus, A. superpictus, and A. hurcanus dominate in almost all reservoirs in the nezhnesurkhan district. however, A. superpictus is rarely found together with $A$. pulcherrimus, and with $A$. hurcanus in our collections did not come across at all. The larvae of A. pulcherrimus and A. hurcanus were more common.

A. pulcherrimus inhabits the rice fields of the above-floodplain terraces of the Surkhandarya 
river. A. superpictus was found here in small numbers. This mosquito lays its eggs exclusively in ground water. Spring waters, which are biotopes of this species, are characterized by high hardness (over $20 \%$ ) by their chemical properties. deg.), a significant content of chlorine (from 40 to $600 \mathrm{mg} / \mathrm{l}$ ), have a lot of sulfuric acid salts and a small oxidizability, not exceeding $4 \mathrm{mg}$ of oxygen per $1 \mathrm{l}$. Data from chemical analysis of water from mass breeding sites $A$. superpictus, show that the water in them is soft, the total hardness does not exceed $10 \%$. deg., chlorine no more than $16 \mathrm{mg} / \mathrm{l}$. We consider the absence of decomposition products of organic substances in the water, full transparency and good warming up of it to be a prerequisite for breeding sites of this species.

In our studies, these factors also determined the nature of the biotope of this mosquito. It should be noted that its larvae freely transfer a significant content of chlorine and sulfuric acid salts in water. We observed their settlement of puddles located in the floodplain of rivers, where the water was bitterly salty, and the edges of the reservoir were covered with white salt. The development of A. superpictus larvae requires soluble calcium, which is rich in ground water.

In Surkhandarya regions, A. superpictus larvae strongly predominate in collections from ground water that protrude to the daytime

surface in mountain river valleys, on the periphery of river discharge cones, at the base of river terraces, at the bottom of ditches, discharges, reserves, and other relief depressions.

The larva of A. pulcherrimus are particularly prevalent in riparian zabolochennaya rivers, the Amu Darya and Surkhandarya, as well as in swamps and seepage of waste origin in the conditions of irrigated agriculture in nizhneserginskom area. A. claviger and C. martinii were observed episodecast, often vesnoy and fall in swamps and kollektornodrainage network.

Having studied the distribution of mosquito larvae in reservoirs of various types, it can be noted that floodplains of rivers that are places of mass breeding of A. pulcherrimus, $A$. superpictus and $A$. hurcanus larvae are of great epidemiological importance. In the pre-Adyr part, A. superpictus, A. slaviger, and A. hurcanus are flattened in springs. $C$. hortensis and C. longiareolata are typical for the springy infiltration swamps of the mountain part.

A. superpictus with A. m. v. sacharovi and Ae. caspius caspius is often found in rodent burrows in the Surkhandarya river valley. In the caves of the floodplain of this river, $A$. superpictus was found only in October, and the extreme humidity in them seems to be unfavorable for summer days (table 2).

\section{Table 2}

The degree of dominance of mosquito species caught in the caves of the Surkhandarya river floodplain, in \%

\begin{tabular}{|c|c|c|c|c|c|}
\hline № & View & July & August & September & October \\
\hline 1 & Culiseta longiareolata & 25,0 & 9,7 & 23,1 & 22,2 \\
\hline 2 & Ur. unguiculata & 6,7 & - & 3,8 & 27,9 \\
\hline 3 & C. pusillus & - & 12,9 & 7,7 & 5,5 \\
\hline 4 & C. pipiens & 62,6 & 64,5 & 50,0 & 16,7 \\
\hline
\end{tabular}




\begin{tabular}{|c|c|c|c|c|c|}
\hline 5 & A. superpictus & - & - & - & 5,5 \\
\hline 6 & A. pulcherrimus & - & 9,7 & 11,6 & 22,2 \\
\hline 7 & Ae. caspius caspius & 6,2 & 3,2 & 3,8 & - \\
\hline
\end{tabular}

A. pulcherrimus was found in large numbers in yurts (Kepp) with domed cloth or wicker thatched roofs, under sheds for livestock, in temporary reed huts on rice plantations and melons in the lower Surkhansky district; in relatively small numbers - in rooms for animals in more lighted areas under a small draft. This species is also found in vegetation and various outbuildings with an optimal humidity of 35-45 $\%$. Males and females fly out of the reservoir and immediately populate caves with high humidity (table 2). a pulcherrimus, unlike other exophilic species of mosquitoes, gets into caves more often, the higher the temperature and lower the humidity in them.

Based on the above, we can draw the following conclusion. Our research of Surkhandarya regions has shown that $A$. hurcanus and $C$. modestus live exclusively in reed-reed thickets of floodplain wetlands of rivers and in places where ground and spring waters are wedged out. The main factors that determine the attraction of females to certain plant communities are relative humidity and temperature. In various types of grassy thickets with relative humidity below $50 \%$ and temperature above $30^{\circ} \mathrm{C}$, A. hurcanus was not found at all. This view, as well as Ae. caspius, flies into homes and livestock premises solely in search of food. A small part of the mosquitoes that flew in at night, remains here for the day. Usually A. hurcanus sits on the wall closer to the floor, and Ae. caspius-closer to the ceiling.

Based on the above, we can draw the following conclusion. Our research of Surkhandarya regions has shown that $A$. hurcanus and $C$. modestus live exclusively in reed-reed thickets of floodplain wetlands of rivers and in places where ground and spring waters are wedged out. The main factors that determine the attraction of females to certain plant communities are relative humidity and temperature. In various types of grassy thickets with relative humidity below $50 \%$ and temperature above $30^{\circ} \mathrm{C}$, A. hurcanus was not found at all. This view, as well as Ae. caspius, flies into homes and livestock premises solely in search of food. A small part of the mosquitoes that flew in at night, remains here for the day. Usually A. hurcanus sits on the wall closer to the floor, and Ae. caspius-closer to the ceiling.In nature, $A$. hurcanus and $C$. modestus are usually located in the lower tier of vegetation, closer to the surface of water or soil, as well as in depressions of the earth. Depending on the air temperature, these mosquitoes migrate horizontally or vertically along the stems during the day. On cool days, at 23-25 O, they crawl up the stems and stay at a considerable distance from the soil surface, while at temperatures above 300 they fall down. From the third decade of July to the second decade of August, these species occasionally meet along the banks of ditches and in the coastal part of rice fields, and on hotter days they inhabit mainly reed-reed swamps and directly rice crops. This, obviously, can be explained by the fact that the water under the vegetation is heated by the sun's rays more slowly than the soil of the coastal part. From the third decade of August, as the temperature decreases, females of these species are found in coastal thickets. Our observations of the process of crawling of $A$. hurcanus samov in the conditions of the cage (August 12 at $2 \mathrm{PM}$ ) showed that for 3-5 minutes. The female can cover up to $1 \mathrm{~m}$ of ground. 
Along with A. hurcanus and C. modestus, there are C. martinii, Ur. Unguiculata, $C$. longiareolata, C. annulata var. subochrea, M. richiardii, rarely - Ae. caspius caspius, C. pipiens, Ae. vexans. The last three species, compared to $A$. hurcanus and $C$. modestus, live in vegetation at higher temperatures and relatively low humidity.

According to our data, among the species of Anopheles fauna in showstitial allocated A. superpictus and $A$. pulcherrimus, in their waterloving - A. algeriensis and A. claviger; with regard to $A$. hurcanus it is known as a relatively flagylbuy look.

Comparison of the obtained data on the distribution of exophilic species of bloodsucking mosquitoes throughout the season in nature shows that the largest population of mosquitoes is found in reed-reed thickets (mixed areas of diaries) located near their breeding sites; they are populated to a much lesser extent. This is explained by the absence of males and young females in multi-day diaries, which generally make up more than $50 \%$ of the mosquito population in mixed diaries, in particular in reed-reed thickets. Consequently, the distance from the place of day-care to the place of breeding has a great influence on the distribution of mosquitoes in different types of diaries in nature.

\section{REFERENCES}

1. Gutsevich A. B., Monchadsky A. C., Stackelberg A. A. " Mosquitoes (family Culicidae» In the book: "Fauna of the USSR.
Insects Diptera", vol. 3, issue 4, L.: "Science", 1970, 384s.

2. Jahangirov S. M., Nurmamatov S., R. A. Hamzayev "Tibby entomology". UV thanme. Samarkand. "Neurs polygraph". 2016. $20 \mathrm{C}$

3. Zvantsov A. B., Ezhov M. N., Artemyev M. M. "Vectors of malaria" (Diptera, Culicidae, Anopheles) CIS. / / - Copenhagen: who. 2003. - 213C.

4. Lebedeva N. I. "Express schemes for determining malarial mosquitoes in Uzbekistan". // Mate. International. Scientific-practical Conf. "Ecological bases of studying the problems of the Aral sea region". - Nukus, 1999. - Pp. 87-88.

5. Jalilov J.J. Reasons and indicators of childhood disability in Surkhandarya region. Infection, immunity and pharmacology. №4/2020y. Tashkent/ 71-77c.

6. Mardanova G. D. "Wintering of bloodsucking mosquitoes in the floodplains of the Surkhandarya river". International scientific journal "Path of science", Russia. Volgograd. 2019. No. 11 (69). Pp. 19-22. ISSN 2311-2158.

7. Jalilov J.J. The role of medical workers and scringing centers in preventing the birth of children with disabilities in the Surkhandarya region. New day in medicine // International scientific journal. № 26.12.2019 y. 28-32c.

8. Muminov M. S., Zhakhongirov sh. M., Khoshimov S. M. "Entomological situation in potential malaria foci of Surkhandarya and Kashkadarya regions". "Doctor's Bulletin", 2007, no. 1, p. 82. 